\title{
Impact of artificial snow and ski-slope grooming on snowpack properties and soil thermal regime in a sub-alpine ski area
}

\author{
Thomas Keller,${ }^{1,2}$ Christine PIELMEIER ${ }^{3}$ Christian RIXEN ${ }^{3}$ Florian Gadient, ${ }^{2,4}$ \\ David GUSTAFSSON ${ }^{3}$ Manfred STÄHLI ${ }^{2,3}$ \\ ${ }^{1}$ Department of Soil Sciences, Swedish University of Agricultural Sciences (SLU), P.O. Box 7014, S-75007 Uppsala, Sweden \\ E-mail: thomas.keller@mv.slu.se \\ ${ }^{2}$ Institute of Terrestrial Ecology, Swiiss Federal Institute of Technology ETH Zürich, Grabenstrasse 3, CH-8952 Schlieren, Switzerland \\ ${ }^{3}$ WSL Swiss Federal Institute for Snow and Avalanche Research SLF, Flüelastrasse 11, CH-7260 Davos-Dorf, Switzerland \\ ${ }^{4} B+S$ Ingenieur AG, Muristrasse 60, CH-3000 Bern 16, Switzerland
}

\begin{abstract}
Earlier studies have indicated that the soil on groomed ski slopes may be subjected to more pronounced cooling than the soil below a natural snowpack. We analyzed the thermal impacts of ski-slope preparation in a sub-alpine ski resort in central Switzerland (1100 m a.s.l.) where artificial snow was produced. Physical snow properties and soil temperature measurements were carried out on the ski slope and off-piste during winter 1999/2000. The numerical soil-vegetation-atmosphere transfer model COUP was run for both locations, with a new option to simulate the snowpack development on a groomed ski slope. Snow density, snow hardness and thermal conductivity were significantly higher on the ski slope than in the natural snowpack. However, these differences did not affect the cooling of the soil, since no difference was observed between the ski slope and the natural snow cover. This might be because cold periods were rare and short and thus any snow pack could protect the soil from freezing. The major impact of the ski-slope grooming was a 4 week delay in snowmelt and soil warming at the end of the season. The newly implemented option proved to be a useful strategy for simulating the snowpack of a ski slope. However, snow density was underestimated by the model as it could not account adequately for compaction due to grooming traffic. Our study demonstrates that there is no site-independent answer as to whether a groomed snowpack affects the thermal conditions in the soil.
\end{abstract}

\section{INTRODUCTION}

In the Alps, many ski resorts are situated at 1000$1500 \mathrm{~m}$ a.s.l. The effect of climate warming on snow conditions is tending to make it more difficult to ski at this altitude (Bürki and Elsasser, 2000), while increasing demand from ski tourists has already prolonged the skiing season from November to April. Accordingly, the production of artificial snow and ski-slope preparation has gradually been intensified (Mosimann, 1998).

Mellini (1996) and Newesely (1997) investigated the thermal soil conditions on and beside a ski slope and found a more pronounced cooling on the ski slope and a delayed thaw during spring. Any change in soil thermal conditions due to a marked alteration of the thermal properties of the snowpack is likely to influence the growth and composition of plant species on ski slopes over the long term (Cernusca and others, 1989).

Numerical simulation models have been developed that simulate natural snowpack development. Usually, such models are driven by standard meteorological measurements and describe the most important processes regulating snow accumulation, settlement and melting, and in many cases heat and water fluxes from/to the soil. For a modified ski slope, however, simulations cannot be based solely on meteorological data, but must also include information about artificial snow production and ski-slope grooming. However, the rate of snow production and its distribution, as well as snow compaction due to grooming, are difficult to determine. Lehning and others (1999) proposed the use of repeated observations of snow depth and snow density to drive the simulation of natural snow covers where no precipitation measurements are available. Grooming may also lead to a considerably altered albedo compared with a natural snowpack (Nakamura and others, 1998).

The aim of this work is (a) to test a new model option for simulating heat dynamics in and below a ski-slope snowpack, and (b) to study differences in snow thermal properties between a ski slope and an undisturbed off-piste snowpack and their influence on the soil temperatures below.

\section{MATERIALS AND METHODS}

\section{Experimental site}

The study was carried out on a southeast-facing slope (1100 $\mathrm{m}$ a.s.l.) at the Brunni-Haggenegg ski resort in the Alptal valley, central Switzerland, during winter 1999/2000. 
The soil here is classified as a Dystric Gleysol (FAO, 1988). The mean air temperature from November 1999 to March 2000 was $-0.7^{\circ} \mathrm{C}$, with the lowest air temperatures at night around $-15^{\circ} \mathrm{C}$. The accumulated precipitation during the study period was $1121 \mathrm{~mm}$. Grooming of the ski slope together with artificial snow production started in midNovember. Snow was produced intensively in early winter until January, when sufficient snow had accumulated.

\section{Measurements}

Air temperature, global radiation and soil temperature at $0.03,0.2,0.5$ and $1.0 \mathrm{~m}$ depth were measured continuously on the groomed ski slope and next to the ski slope where the snow cover was undisturbed. Soil temperature was measured using Yellow Springs Instrument Co. thermistors with an accuracy of $\pm 0.5^{\circ} \mathrm{C}$. Precipitation, relative humidity and wind speed were recorded at a nearby meteorological station.

Snow depth and snow density were manually recorded approximately once a week using an avalanche probe and a steel cylinder (diameter $0.1 \mathrm{~m}$, length $1.2 \mathrm{~m}$ ), with three replications per site. After mid-December, the snow on the ski slope was too hard to allow snow-density measurements. At the end of the skiing season, we measured the snow density on the ski slope by excavating a sample of known volume.

On 12 January, we made a detailed survey of snow properties on and next to the ski slope. Density profiles were determined using a steel cylinder (volume $0.001 \mathrm{~m}^{3}$ ). Thermal conductivity was measured for the uppermost snow layers using ISOMET 104. A constant heat impulse was led into the snow via the needle of the probe (length $0.1 \mathrm{~m}$ ), and the temperature response of the snow was measured (Sturm and Johnson, 1992). Snow hardness was measured using the high-resolution penetrometer Snow MicroPen (Schneebeli and Johnson, 1998). Measurements were taken perpendicular to the snow surface to $0.25 \mathrm{~m}$ depth, with three replications per site.

\section{Model description}

We used the one-dimensional numerical SVAT (soil-vegetation-atmosphere transfer) model COUP (Jansson and Karlberg, 2001), extended with the snow model SNTHERM of Jordan (1991). The COUP model has frequently been applied to winter locations (e.g. Johnsson and Lundin, 1991; Stähli and others, 1995; Stadler and others, 1997; Gustafsson and others, 2001) and has thus become a suitable tool for studying practical issues related to snow and frost. It calculates combined heat and water fluxes in a layered soil profile and the overlying snowpack. The two basic assumptions for the soil are the Richards equation (Richards, 1931) for water flow and the Fourier law for heat flow. The boundary conditions are determined by formulations of lateral subsurface flow, percolation, surface heat balance and geothermal heat flux. The model is driven by standard meteorological data. A complete model description is given in Jansson and Karlberg (2001).

The snowpack is considered to consist of layers of varying density and thickness. A perfectly frozen fresh snow layer is assumed to have a minimum density of $\rho_{\mathrm{smin}}$.
Settling of the snowpack is a function of destructive metamorphism, overburden pressure and snowmelt:

$$
\mathrm{CR}=-\frac{1}{z_{\text {layer }}} \frac{\partial z_{\text {layer }}}{\partial t}=\mathrm{CR}_{\text {metam }}+\mathrm{CR}_{\text {overb }}+\mathrm{CR}_{\text {melt }}
$$

where $\mathrm{CR}$ is the compaction rate $\left(\mathrm{s}^{-1}\right)$ and $z_{\text {layer }}(\mathrm{m})$ is the layer thickness.

In order to account for artificial snow production and ski-slope grooming, for which there is usually no quantitative information available, a new option was added to the model, enabling the simulated snow depth to match observed snow-depth measurements when these were available. If there is a deficit of simulated snow depth compared to the measurement, a snow water equivalent corresponding to the snow-depth deficit and the actual snow density of the uppermost snow layer before adjustment is added. When a snow-depth surplus is simulated, all snow layers above the measured snow depth are removed.

Snow temperatures are derived from an energy-balance calculation for each snow layer. The albedo of the snow surface varies between a maximum value, representing newfallen snow, and a minimum value, representing old dusty snow, and is calculated according to Plüss (1996), with age of the snow and positive air temperatures as ageing factors. Snow grooming is expected to alter the albedo of the skislope snow cover significantly, but due to lack of experimental data or alternative mathematical approaches for snow albedo on a ski slope, we used the same albedo function for both natural and groomed snow covers. However, a faster decline of the albedo on the groomed ski slope was assumed. Heat transport through the snowpack occurs by conduction and vapour diffusion. For each snow layer an effective thermal conductivity, $k_{\text {eff }}$, is calculated:

$$
k_{\text {eff }}=k_{\text {snow }}+L_{v, \text { ice }} D_{\text {eff }} C_{k t},
$$

where $L_{v}$,ice is the latent heat of sublimation at $0^{\circ} \mathrm{C}, D_{\text {eff }}$ is an effective diffusion coefficient for water vapour in snow, $C_{k t}$ is the variation of equilibrium vapour density with temperature (Jordan, 1991) and $k_{\text {snow }}$ is the thermal conductivity of snow, expressed as

$$
k_{\text {snow }}=k_{\text {air }}+\left(p_{1} \rho_{\text {snow }}+p_{2} \rho_{\text {snow }}^{2}\right)\left(k_{\text {ice }}-k_{\text {air }}\right),
$$

where $\rho_{\text {snow }}$ denotes snow density, $k_{\text {ice }}$ and $k_{\text {air }}$ are the thermal conductivity of ice and air, and $p_{1}$ and $p_{2}$ are two fitting coefficients.

The thermal conductivity of the mineral soil is calculated according to the formula suggested by Kersten (1949). The model approach to simulating soil freezing and thawing, with its implication for the soil water fluxes, is described in Stähli and others (1995).

\section{Model application and parameter setting}

The model was applied to both the off-piste site and the ski slope for the period October 1999-May 2000. Hourly mean values of air temperature, relative humidity, wind speed, precipitation and global radiation were inputs to the model. The snow adjustment routine was only applied to the skislope site. The parameterization for the surface heat exchange was mainly based on the work of Gustafsson and others (2001). At the lower boundary of the $3 \mathrm{~m}$ deep soil profile, a sinusoidal annual temperature cycle was calculated, including the mean air temperature, the annual air-temperature amplitude and the damping and phase shift 

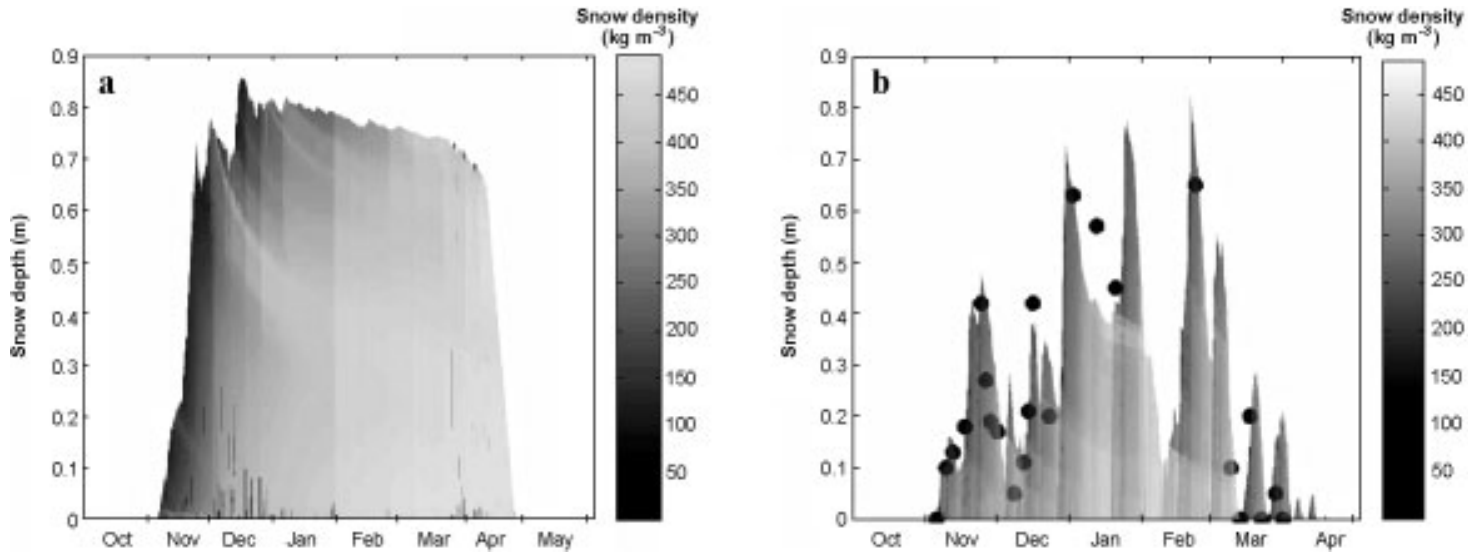

Fig. 1. Simulated snow-depth and snow-density profiles for the ski slope (a) and the off-piste site (b) for winter 1999/2000. For the off-piste site, measured snow depths (black dots) are shown for comparison.

in the soil. The parameterization of the soil physical properties was based on the measurements of Stähli and Stadler (1997) and Stadler and others (1998) who determined the water-retention curve, saturated hydraulic conductivity and the freezing characteristic curve of the Alptal loam in the laboratory. Initial soil temperatures were set according to the measurements, and a nearly saturated soil profile was assumed. For the ski slope, the density of new-fallen snow was assumed to be higher, supposing that this snow was groomed immediately.

\section{RESULTS}

\section{Seasonal development of the snowpack}

On the ski slope, the snow depth was considerably larger than off-piste due to the artificial snow production (Fig. 1). At the off-piste site, the snow disappeared 4 weeks earlier than on the ski slope. For the off-piste site, a satisfactory agreement between simulated and measured snow depth was achieved $\left(R^{2}=0.83\right)$. With regard to snow density, a considerable increase was noticed throughout the winter season. The groomed ski slope had a density of $500 \mathrm{~kg} \mathrm{~m}^{-3}$ in mid-December and gradually compacted to become a mixture of hard snow and pure ice lenses with a maximum density of $700 \mathrm{~kg} \mathrm{~m}^{-3}$. At the off-piste site, we measured a density of $400 \mathrm{~kg} \mathrm{~m}^{-3}$ at the end of winter. The snow-density pattern with layers of low density in early winter and after new snowfalls, which later settled to layers of higher density, was reflected adequately by the model. A direct comparison of simulated and observed snow-density profiles was made for 12 January (Fig. 2). In the natural snowpack, densities were simulated in accordance with the measurements. For the ski slope, the model simulated distinct layers of varying densities, indicating that groomed ski slopes are not homogeneous, which was confirmed by measurements. However, the model generally underestimated snow density on the ski slope, especially towards the end of the season.

On the ski slope, thermal conductivity $\left(0.53 \mathrm{~W} \mathrm{~m}^{-1} \mathrm{~K}^{-1}\right)$, snow density $\left(530 \mathrm{~kg} \mathrm{~m}^{-3}\right)$ and snow hardness $(36 \mathrm{~N})$ were significantly higher than off-piste, where mean values were $0.14 \mathrm{~W} \mathrm{~m}^{-1} \mathrm{~K}^{-1}, 285 \mathrm{~kg} \mathrm{~m}^{-3}$ and $0.6 \mathrm{~N}$, respectively. The measurements confirmed the non-linear relationship between snow density, thermal conductivity and snow hardness (Fig. 3). Our measurements were in good agreement with the thermal conductivity function by Sturm and others
(1997), which is based on an extensive dataset of 488 measurements. For the simulation, the fitting parameters in Equation (3) were changed to $p_{1}=0$ and $p_{2}=0.9 \times 10^{-6}$ compared to the model default values (Jordan, 1991) of $p_{1}=7.75 \times 10^{-5}$ and $p_{2}=1.11 \times 10^{-6}$ (Fig. 3).

\section{Seasonal dynamics of the soil temperatures}

When the snow cover started to develop, the soil-temperature profiles of the two sites did not differ. Large temperature gradients between 0.03 and $0.2 \mathrm{~m}$ depth indicated that cooling from the overlying snow was strongly counteracted by the large heat capacity of the soil due to its high water saturation. The temperatures at $0.03 \mathrm{~m}$ depth decreased too rapidly in the simulation, revealing limitations in the representation of the uppermost, organic-rich soil layer (Fig. 4). At $1.0 \mathrm{~m}$ depth, the cooling of the soil and the rewarming in spring showed satisfactory accordance between model and measurements (Fig. 4). At the beginning of March, soil temperatures reached their minima, but the soil was never frozen. The simulation showed that even during the coldest period, the cooling front in the snowpack did not reach the soil surface for more than 1 or 2 days either on the ski slope

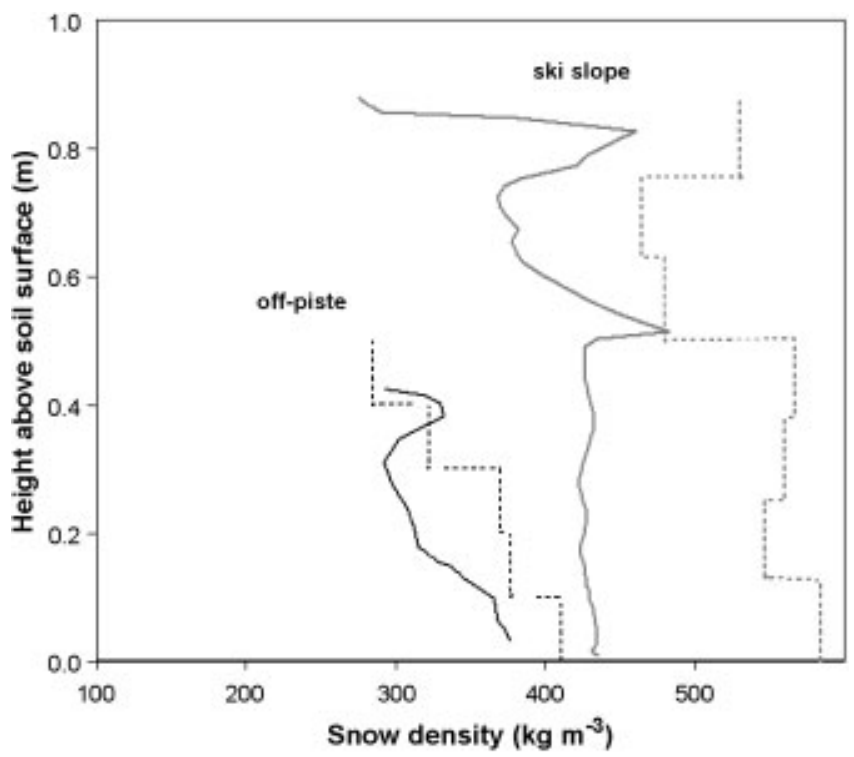

Fig. 2. Measured (dashed line) and simulated (solid line) profiles of snow density at the ski slope and off-piste site on 12 January 2000. 

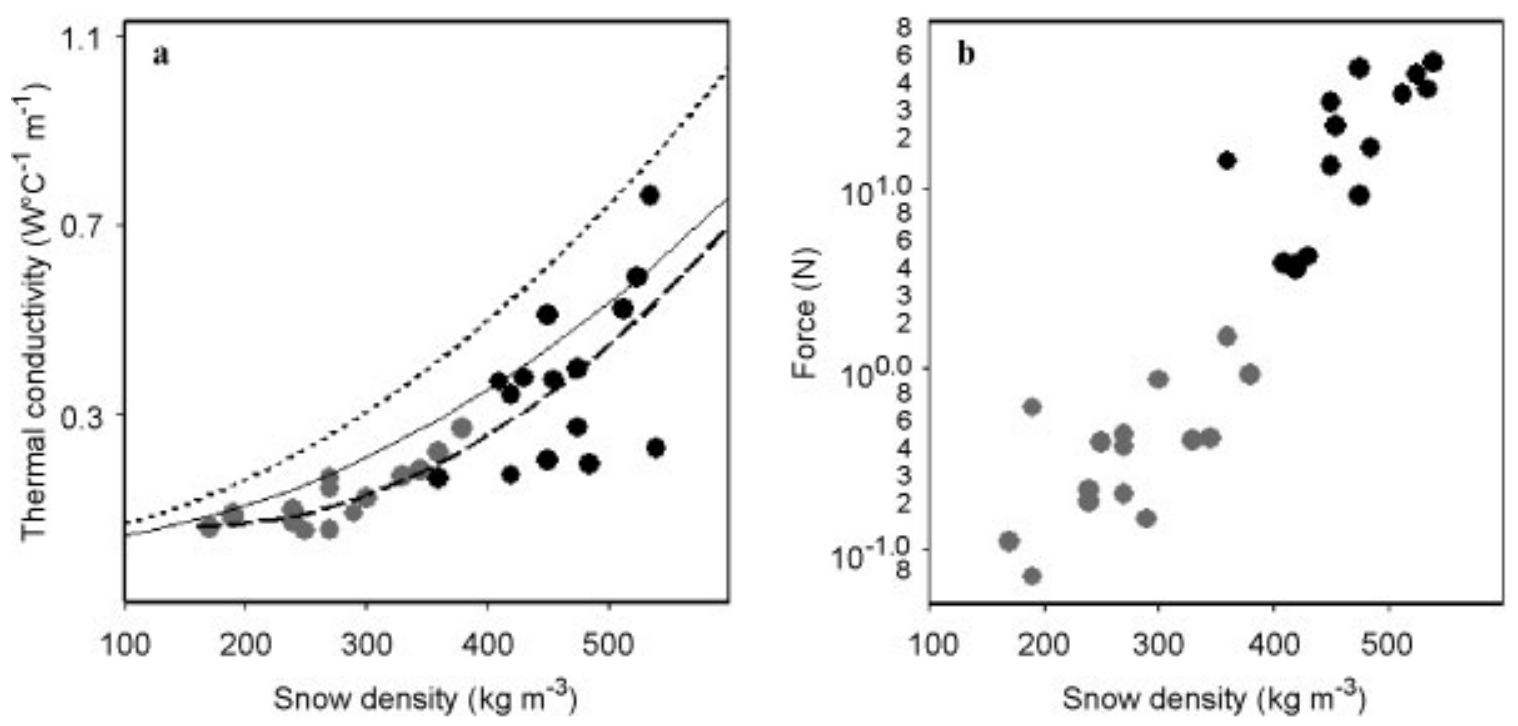

Fig. 3. Relationship between snow density and thermal conductivity ( $a$ ), and between snow density and snow hardness ( $b$ ) measured on 12 January 2000 on the ski slope (black dots) and in the natural snowpack (grey dots). In (a) the model function for $k_{\text {snow }}$ (Equation (3)) is indicated (solid line), representing the fitted parameters $p_{1}$ and $p_{2}$, and (dotted line) with the default parameter values (Jordan, 1991). The function suggested by Sturm and others (1997) is also shown (dashed line).

or at the off-piste site. As soon as the snow cover had melted completely in spring, the temperatures in the uppermost soil layers increased rapidly. No significant differences between ski slope and off-piste could be noted except for the snowmelting period at the end of the winter, which was confirmed by the model simulations.

\section{DISGUSSION AND GONGLUSIONS}

The soil below the intensely groomed ski slope was not subjected to greater cooling than the soil below the natural snowpack. This contradicts the findings of other studies (Mellini, 1996; Newesely, 1997). Our results can be explained



Fig. 4. Simulated and measured soil temperatures at 0.03 and $1.0 \mathrm{~m}$ depth for the off-piste site and the ski slope. 
by the fact that the snow depth on the ski slope was greater, due to artificial snow production, than the snow depth of the natural snow cover. This counteracted the reduced insulation properties (i.e. higher thermal conductivity) of the snowpack resulting from the higher density due to intense grooming (Rixen and others 2002). Also, the climate at our sub-alpine site differs significantly from that at the alpine sites of other studies (Mellini, 1996; Newesely, 1997). Mean air temperature during winter is only slightly below $0^{\circ} \mathrm{C}$ at our site (1100 m a.s.l.), which is several ${ }^{\circ} \mathrm{C}$ warmer than in alpine areas. Hence, during the winter in question, cold periods were too short to produce soil frost for any kind of snowpack. Also, the rather wet soil at our site has a large heat capacity which might prevent the soil from freezing. Both the relatively mild climate and the wet soil can be considered typical of sub-alpine areas in central Switzerland.

The major effect of ski-slope grooming and artificial snow production was a delay in snowmelting and soil warming at the end of the season. We observed a delay of 4 weeks, which might be significant with regard to the vegetation season or hydrological processes.

The newly implemented option proved to be a useful strategy for simulating the seasonal snow-cover development on a ski slope. The main goal was to provide the best possible boundary conditions to the soil in order to calculate heat and water fluxes below a ski slope. By adjusting the simulated snow depth to measurements, artificial snow production and grooming were included for which there was no quantitative information available. Lehning and others (2002) applied this model strategy successfully where automatic weather stations provided input data (snow depth). However, the model underestimated snow density for the ski-slope snowpack, especially towards the end of winter. This discrepancy is probably caused by the fact that the model does not account for the mechanical compaction of the snow cover due to grooming-machine traffic. Accounting for this compaction by applying a higher density for new snow does not adequately describe this process. Deeper snow layers are also compacted by grooming machines. We suggest two possible ways of improving the model: either not only snow depth but also snow density should be adjusted to measurements; or the model should be extended with a function accounting for compaction due to grooming traffic.

Our study demonstrates that there is no site-independent answer as to whether a groomed snowpack affects thermal conditions in the soil. For ski resorts where new snowing facilities are planned, it is necessary to individually assess what impact artificial snow production and snow compaction have on the soil. Models must incorporate soil chemical aspects, influence on the growing season and plant-growth response to thermal conditions.

\section{ACKNOWLEDGEMENTS}

We would like to thank H. Wunderli (ETH Zürich) for valuable technical support. Financial support was received from ETH Zürich Research Council, the Swiss Agency for the Environment, Forests and Landscapes (BUWAL), the Swiss cantons Valais and Grisons and the Swiss National Science Foundation, project No. 2100-055810.98.

\section{REFERENGES}

Bürki, R. and H. Elsasser. 2000. Touristische Nachfragetrends und Klimawandel in den Alpen. Montagna, 1/2, 13-16.

Cernusca, A., H. Angerer, Ch. Newesely and U. Tappeiner. 1989. Ökologische Auswirkungen von Kunstschnee - eine Kausalanalyse der Belastungsfaktoren. Verh. Gesells. Ökologie, 19, 746-757.

FAO (United Nations Food and Agriculture Organization). 1988. FAO/Unesco soil map of the world, revised legend. Wageningen, United Nations Food and Agriculture Organization. International Soil Reference and Information Centre. (World Resources Report 60, ISRIC Technical Paper 20.)

Gustafsson, D., M. Stähli and P.-E. Jansson. 2001. The surface energy balance of a snow cover: two different simulation models and measurements. Theor. Appl. Climatol., 70(1-4), 81-96.

Jansson, P.-E. and L. Karlberg. 2001. Coupled heat and mass transfer model for soil-plant-atmosphere systems. Stockholm, Royal Institute of Technology. Division of Land and Water Resources.

Johnsson, H. and L.-C. Lundin. 1991. Surface runoff and soil water percolation as affected by snow and frost. F. Hydrol., 122(1-4), 141-159.

Jordan, R. 1991. A one-dimensional temperature model for a snow cover: technical documentation for SNTHERM.89. CRREL Spec. Rep. 91-16.

Kersten, M.S. 1949. Thermal properties of soils. Minneapolis, MN, University of Minnesota. Engineering Experimental Station. (Bulletin 28.)

Lehning, M., P. Bartelt, B. Brown, T. Russi, U. Stöckli and M. Zimmerli. 1999. SNOWPACK model calculations for avalanche warning based upon a new network of weather and snow stations. Cold Reg. Sci. Technol., 30(1-3), 145-157.

Lehning, M., P. Bartelt, B. Brown and C. Fierz. 2002. A physical SNOWPACK model for the Swiss avalanche warning service. Part III. Meteorological forcing, thin layer formation and evaluation. Cold Reg. Sci. Technol., 35(3), 169-184.

Mellini, K. 1996. Skipisten und Permafrost. (Diplomarbeit, University of Zürich. Department of Geography.)

Mosimann, T. 1998. Beschneiungsanlagen in der Schweiz. Weitere Entwicklung Umweltverträglichkeit und Folgerungen für die Prüfung und Bewilligung von Beschneiungsanlagen. Bubendorf and Hannover, Terragon Ecoexperts AG, Bubendorf, and Physical geography and Landscape Ecology Department, University of Hannover. (Studie im Auftrag des Schweizerischen Verbandes der Seilbahnunternehmungen.)

Nakamura, T., R. Tamura, T. Ohta and O. Abe. 1998. Experimental study on the spectral reflectance of snow. In ISSW'98. International Snow Science Workshop, 27 September-1 October 1998, Sunriver, Oregon. Proceedings. Seattle, WA, Washington State Department of Transportation, 214-224.

Newesely, C. 1997. Auswirkungen der künstlichen Beschneiung von Schipisten auf Aufbau, Struktur Gasdurchlässigkeit der Schneedecke, sowie auf den Verlauf der Bodentemperatur und das Auftreten von Bodenfrost. (Ph.D. thesis, Universität Innsbruck.)

Plüss, C. G. 1996. The energy balance over an Alpine snowcover - point measurements and areal distribution. (Ph.D. thesis, Eidgenössische Technische Hochschule Zürich. Geographische Institut.) (Dissertation 11641.)

Richards, L. A. 1931. Capillary conduction of liquids in porous mediums. Physics, 1, 318-333.

Rixen, C., V. Stöckli and W. Amman. 2002. Does artificial snow production affect soil and vegetation of ski pistes? A review. Pers. Plant Ecol., 5(4), 219-230.

Schneebeli, M. and J. B. Johnson. 1998. A constant-speed penetrometer for high-resolution snow stratigraphy. Ann. Glaciol., 26, 107-111.

Stadler, D., H. Flühler and P.-E. Jansson. 1997. Modelling vertical and lateral water flow in frozen and sloped forest soil plots. Cold Reg. Sci. Technol., 26(3), 181-194.

Stadler, D., M. Bründl, M. Schneebeli, M. Meyer-Grass and H. Flühler. 1998. Hydrologische Prozesse im subalpinen Wald im Winter. Zürich, vdf Hochschulverlag AG, Eidgenössische Technische Hochschule. (Schlussbericht NFP 31.)

Stähli, M. and D. Stadler. 1997. Measurement of water and solute dynamics in freezing soil columns with time domain reflectometry. 7 . Hydrol., 195(1-4), 352-369.

Stähli, M., P.-E. Jansson and L.-C. Lundin. 1995. Preferential water flow in a frozen soil - a two-domain model approach. Hydrol. Processes, 10(1), 95-103.

Sturm, M. and J. B. Johnson. 1992. Thermal conductivity measurements of depth hoar. F. Geophys. Res., 97(B2), 2129-2139.

Sturm, M., J. Holmgren, M. König and K. Morris. 1997. The thermal conductivity of seasonal snow. F. Glaciol., 43(143), 26-41. 